\title{
ORCHID SEED STORES FOR SUSTAINABLE USE: A MODEL FOR FUTURE SEED-BANKING ACTIVITIES
}

\author{
Philip T. Seaton \& Hugh W. Pritchard \\ Seed Conservation Department, Royal Botanic Gardens, Kew, Wakehurst Place, Ardingly, \\ West Sussex, RH17 6TN, U.K.
}

\begin{abstract}
AвstRact. Orchid Seed Stores for Sustainable Use (OSSSU) is a three-year UK Darwin Initiative project with the primary objective of setting up a global network of orchid seed banks, focusing initially on orchid biodiversity hotspots in Asia and Latin America. At the time of writing there are 31 participating institutions in 22 countries. In the longer term, our aim is to expand the network to include more institutions from around the world, from African countries in particular. We are confident that good-quality dry orchid seed has the potential to survive for many decades at conventional seed bank temperatures of around - 20 C. Participating institutions have been provided with seed storage tubes, together with funding to purchase a dedicated chest freezer and some consumables. Common protocols have been agreed to allow, for the first time, comparison of germination of seed of more than 250 orchid species from tropical and temperate countries over a wide range of habitat types on one germination medium (Knudson C) and to compare long-term viability. The role of OSSSU in both ex situ and in situ conservation is illustrated by the case of Cattleya quadricolor, a Colombian endemic. The story of $C$. quadricolor is a familiar one: loss of habitat combined with illegal collection of this beautiful species by commercial interests. However, here is a project in which all of the pieces of the orchid conservation jigsaw puzzle fit neatly into place: an up-to-date Red List for the orchids of Colombia to assist with targeting rare and endangered species, a National Action Plan for Cattleya species, participation in OSSSU, a group of amateur and professional growers with the necessary expertise to germinate seed for the project and produce seedlings, a committed commercial grower willing to provide plants for pollination and seed harvest, and a botanical garden willing to act as a focal point and to re-introduce plants of $C$. quadricolor raised by the project into a number of secure sites.
\end{abstract}

Resumen. Los Almacenes de Semillas de Orquídeas para Uso Sostenible (Orchid Seed Stores for Sustainable UseOSSSU por sus siglas en inglés) es una iniciativa de tres años del proyecto Iniciativa Darwin del Reino Unido, con el principal objetivo de establecer una red global de bancos de semillas de orquídeas, enfocándose inicialmente en aquellos "puntos calientes" de biodiversidad en Asia y América Latina. Al momento de escribir este documento, hay 20 instituciones participantes en 16 países. A más largo plazo, nuestro objetivo es el de incluir un mayor número de instituciones de todo el mundo, y especialmente de países africanos. Tenemos la confianza de que una semilla seca de orquídea de buena calidad tiene el potencial sobrevivir durante muchas décadas bajo condiciones de temperatura de un banco de semillas convencional de alrededor de -20 C. Las instituciones participantes han recibido tubos para el almacenamiento de semillas, junto con los fondos para adquirir una congeladora de baúl específicamente dedicada así como algunos de los suministros consumibles necesarios. Se ha acordado una serie de protocolos, que por primera vez permitirán la comparación de la germinación de semillas de más de 250 especies de orquídeas de países tropicales y templados que cubren una amplia gama de tipos de hábitat en un solo medio de germinación (Knudson C) y compararlas con su viabilidad de largo plazo. El rol de la OSSSU tanto en conservación ex situ e in situ queda ilustrado con el caso de Cattleya quadricolor, una endémica colombiana. La historia de C. quadricolor es algo muy familiar: pérdida de hábitat combinada con la ilegal recolección de esta especie tan hermosa debido a intereses comerciales. Sin embargo, aquí tenemos un proyecto en el cual todas las piezas del rompecabezas de la conservación de orquídeas calzan en forma exacta: una Lista Roja actualizada para las orquídeas de Colombia que sería de gran ayuda para apuntar a las especies raras y amenazadas, un Plan Nacional de Acción para las especies de Cattleya, la participación en OSSSU, un grupo de cultivadores amateur y profesionales con los conocimientos 
necesarios para germinar las semillas para el proyecto y estar en capacidad de producir plántulas, un cultivador comercial comprometido que esté dispuesto a proporcionar plantas para polinización y realizar la cosecha de semillas, y un jardín botánico que está dispuesto a actuar como punto focal para re-introducir plantas de $C$. quadricolor cultivadas por el proyecto a un número de sitios que ofrezcan seguridad.

KEY wORDS: orchids, seed stores, Cattleya quadricolor, conservation

The time has arrived to begin banking orchid seeds as a key component of an effective ex situ conservation strategy. As long ago as 1984 at the Miami World Orchid Conference it was agreed that orchid seed banking had the potential to make an invaluable contribution to orchid conservation (Anonymous, 1985). Twenty-five years later, as it is becoming increasingly apparent that in situ techniques cannot by themselves be sufficient to save all of the world's orchids, ex situ techniques are once again recognized as being an essential component of any future integrated conservation strategies (Swarts \& Dixon, 2009). Seed banking has been recognized as being the most efficient way of storing large numbers of living plants in one place (FAO, 1996; Linington \& Pritchard, 2001).

Adopted in 2002 by the Conference of the Parties of the Convention on Biological Diversity (CBD), the long-term goal of the Global Strategy for Plant Conservation (GSPC) was (and remains) to halt the current and continuing loss of plant biodiversity through the setting of 16 outcome-oriented targets for 2010. The most significant from an ex situ perspective is target 8: to have $60 \%$ of threatened plant species in accessible ex situ collections, preferably in the country of origin, and $10 \%$ of them included in recovery and restoration programs (http://www. bgci.org/plants2010/t8/). As 2010 approaches, the question we should be asking is: "How far has the orchid community progressed in terms of meeting the above targets?" Indeed, one could also ask if the target was realistic and attainable within the given time frame.

Orchid Seed Stores for Sustainable Use (OSSSU), a Darwin Initiative funded by Defra (the UK government's Department for Environment, Food and Rural Affairs) was originally conceived by Hugh Pritchard and Phil Seaton as a project with the modest aim of storing seeds representing 250 orchid species over a period of three years. Assuming that there are approximately 25,000 orchid species (Dressler, 2005), this would represent around $1 \%$ of the world's orchid flora. At the time of writing this target has already been exceeded by a considerable margin.

Through the funding of collaborative projects that draw on UK biodiversity expertise, Darwin Initiative projects are awarded with the aim of assisting countries that are rich in biodiversity to meet their objectives under one or more of the major biodiversity Conventions (in the case of OSSSU, the Convention on Biological Diversity - the CBD). Accordingly, OSSSU initially focused on orchid-rich countries in Asia and Latin America. At the beginning of the project, participants from China, India, Indonesia, the Philippines, Singapore, Thailand, and Vietnam were invited to a workshop in Chengdu, China. Participants from Bolivia, Brazil, Chile, Colombia, Costa Rica, Cuba, Ecuador, and Guatemala attended a workshop at Quito Botanical Gardens, Ecuador (Seaton \& Pritchard, 2008). Although the world's orchid biodiversity hotspots are mainly concentrated in the tropics (Cribb \& Govaerts, 2005), there are also important orchid biodiversity hotspots in cooler regions, explaining the inclusion of the temperate orchid floras of China and Chile.

The workshops provided the opportunity to exchange expertise and ideas and develop common protocols. Participants reflected the wide range of scientific backgrounds and experience found within the membership of the orchid community - from orchid biotechnologists to field biologists -- each contributing his or her own experience and expertise to the project. Once a formal agreement had been signed (a Memorandum of Understanding) with a participating country, the Darwin Initiative provided modest funding to enable each participating country to purchase a small chest freezer dedicated to storing orchid seed at $-20 \mathrm{C}$, plus some consumables. Participants were also supplied with suitable seed-storage vessels.

Despite an early report that some orchid seed retained some viability after storage for up to 20 years under less than ideal conditions (Knudson, 1954), at the time of the 1984 World Orchid Conference there 
remained a lack of numerical data for initial germination percentage enabling comparisons to be made with later samplings of stored seed. Although doubts continue to be expressed concerning the potential longevity of orchid seed in dry storage (Neto \& Custodio, 2005), part of the problem may lie in the definition of the terms 'long-lived' and 'short-lived'. Certainly a number of studies have shown that, as long as the seed is dried correctly, good-quality seed of many orchid species are likely to remain viable for many decades when stored at $-20 \mathrm{C}$ (Seaton \& Pritchard, 2003). Nevertheless, the number of species tested has so far been relatively limited. One of the many strengths of OSSSU is that germination data will become available for more than 250 species across many genera in many countries and many different habitats around the globe. All seed accessions will be tested on one medium, Knudson C (Knudson, 1946), to allow a direct comparison to be made between the responses of species and genera. This will be the first time that such information will become available for such a wide range of material. In addition, a sample of each seed lot will be sown on a second medium as a comparison. We already know that Knudson $\mathrm{C}$ is not the most suitable medium for all species. Some species may, for example, have a higher percentage germination on Murashige and Skoog medium (Murashige \& Skoog, 1962) than on Knudson C. Other species will indeed have a higher percentage germination on Knudson C. Some species will perform better on other media (Arditti et al., 1982), and participants have the opportunity to select media that, according to their own experience, give the optimum germination percentage for each individual species.

One aim of the project is to publish all of the data at the end of the project period and make it available to the wider orchid community. Each participating institute is committed to promoting the project through a public awareness program, and many partners have already presented posters and given presentations about their work as part of OSSSU. It is no exaggeration to say that the advent of the Internet, with the sudden ease of communication, has made international projects such as OSSSU possible. A key component of any project in the 21 st century is the design and setting up of a website, both to raise the profile of the work being undertaken and provide information to a wider audience. The OSSSU website can be found at http:// osssu.org.

The publication Growing Orchids from Seed was written with the express purpose of making basic seed sowing techniques available to a wide audience (Seaton \& Ramsay, 2005). Not only can the book serve as a basic laboratory manual, the methods described require a minimum of laboratory equipment and are therefore suitable for use where resources are limited. Because a significant proportion of OSSSU partners are in the orchidrich countries of Latin America, OSSSU has sponsored the translation of the information into Spanish, and the book is available as Cultivo de Orquideas por Semillas (Seaton \& Ramsay, 2009). Ideally the information should eventually become available in a wider range of languages. As a first step in this direction, Growing Orchids from Seed has also been translated into Chinese.

At the outset of the project two people at each institution were funded to attend the workshops in an attempt to avoid the possible loss of training/expertise if one of the individuals so trained left the institution. The original personnel have in turn cascaded their training and expertise to a large number of students and permanent staff who are presently engaged in testing the viability of the stored seed at regular intervals. We are seeking answers to a number of important questions. Seed of some orchid species are undoubtedly shorterlived in storage than others (Pritchard et al., 1999), and genera such as the South African Disa (Thornhill \& Koopwitz, 1992) and the Central and South American Stanhopea and Coryanthes retain a reputation for being short-lived. Is this deserved? Are seeds of some genera shorter-lived than others? If this is the case, should we be considering additional storage at $-196 \mathrm{C}$ using liquid nitrogen?

Orchid seed-banking alone, however, cannot be the answer to all of our conservation problems. The obvious question then becomes: what is the purpose of storing orchid seed? One valuable spin-off of OSSSU is that the germination testing inevitably produces seedlings, and these can be used to enhance living collections both for research and educational purposes. In addition, seedlings can potentially be used as part of re-introduction projects.

An example of how OSSSU can contribute to orchid restoration projects is provided by a project 
currently underway in Cali, Colombia (for a detailed account of the project see Seaton \& Orejuela, 2009). Here groups of dedicated conservationists from different backgrounds are working together to produce an effective integrated rescue package to conserve, propagate, and re-introduce Cattleya quadricolor Lindl. (syn. C. chocoensis Linden). This involves members of the Asociación Vallecaucana de Orquideología, Jardín Botánico de Cali, Reserva Natural de Yotoco, Parque Nacional de los Farallones, and the Seed Conservation Department of the Royal Botanic Gardens, Kew.

In response to increasing concern about their status in the wild, an Action Plan has been formulated for the conservation of all Cattleya species in Colombia (Niessen \& Calderón, 2002). Included in the Action Plan was an evaluation of the status of the remaining wild populations, the production of distribution maps, evaluation and enhancement of ex situ collections, and the reintroduction of endangered species. Cattleya quadricolor, a Colombian endemic, has been classified as Endangered (EN) (http:// www.iucnredlist.org/static/categories_criteria) using the the latest IUCN Red List categories (CalderonSaenz, 2007). Although remnant populations remain in dry and transitional humid forests from 600 to 1500 meters above sea level along a narrow strip of territory along the Rio Cauca, extensive habitat destruction and past overcollection have led to the current precarious status of the species.

In June 2005, a study group from a wide range of backgrounds was created within the Asociacion Vallecaucana de Orquideología in Cali with the aim of undertaking an indepth study of the different native Colombian orchid genera. As part of the project they decided to undertake the in vitro production of orchids in danger of disappearing from the wild, including $C$. quadricolor, with the long-term aim of reintroducing them once more into their natural habitats.

The OSSSU project transferred seed storage tubes and some funds to the Jardín Botánico de Cali to assist with the purchase of a small chest freezer, where dry seed of Colombian orchids, including $C$. quadricolor, can be stored, both to act as an insurance policy against future losses of wild populations and to provide material for use in future conservation projects. Germination of stored seed is currently being monitored at regular intervals, thereby contributing to an OSSSU database. It is anticipated that germination testing will continue beyond the end of the project period. The first 500 plants are currently growing with the aim of reintroducing C. quadricolor to sites that are protected from collectors.

However desirable this may be thought to be, from the outset it was not the stated aim of OSSSU to target seed of endangered orchids specifically nor collect orchid seed from the wild. The initial focus was to use plants under cultivation in living collections, cross-pollinating different clones where possible. With the notable exception of some countries such as Colombia, there remains a lack of information about the status of the majority of orchid species in the wild, and few are to be found on the current Global Red Lists (Pimm, 2005). It can therefore be difficult to make informed decisions about which orchid species should be priorities in terms of seed banking. Given the tiny amount of space required to store an individual orchid seed collection, it would seem sensible to store whatever we are able at present and generate as much data as practicable.

The decision to use existing collections was pragmatic. Collecting seed from the wild can be timeconsuming and expensive and requires permission from the appropriate authorities before embarking on such a program. OSSSU does not, however, exclude the use of wild-collected material. In Chile, for example, few of its native species are in cultivation, and the project is indeed focusing on wild-collected seeds. In this instance it is particularly important to develop suitable symbiotic and asymbiotic germination techniques.

The overall strategy is one of capacity-building - the setting up a self-sustaining network of orchid seed banks around the globe for the future - and of gathering and collating data on a wide range of orchid species, thereby providing a sound foundation and knowledge base for future orchid seed bankers and biotechnologists. The project is already expanding to include a number of Associate Members who, at the time of writing, include additional institutions in Brazil and China (including Hong Kong), plus institutions in Europe, the first to join being Estonia, Italy, and Spain (Mallorca). Beyond OSSSU, as the network expands, an updated target has been set to have a minimum of 1000 species in storage, thereby making a significant contribution to achieving GSPC target 8 . 


\section{Conclusion}

Thus far, OSSSU has facilitated the establishment of a global network of orchid seed banks. In addition to storing seed according to a common protocol, the project has generated data on seed-capsule ripening times, seed numbers per capsule, media preferences for more than 250 species, the performance of more than 250 species on a single growth medium (Knudson C), and information on the relative longevity of orchid seeds representing species from a wide range of habitats. The next step is to publish these data and make them available as a resource for horticulturalists and conservationists wishing to store orchid seed and regenerate plant material from that seed. Our longterm aim is to expand the orchid seed banking network to include additional countries and institutions and establish a Global Orchid Facility that brings together the information garnered from OSSSU with the information already available but dispersed throughout the orchid literature and make this available through a dedicated website.

\section{LitERATURE CITED}

Arditti, J., M. A. Clements, G. Fast, G., Hadley, G. Nishimura \& R. Ernst, R. 1982. Orchid seed germination and seedling culture - a manual. Pp. 243370 in: J. Arditti (ed.). Orchid biology: reviews and perspectives, II. Cornell University Press, Ithaca, New York, USA.
Calderón Sáenz, E. (ed.) 2007. Libro rojo de plantas de Colombia. Volumen 6, Orquídeas: primera parte. Instituto Alexander von Humboldt: Ministerio de Ambiente, Vivienda y Desarrollo Territorial, Bogotá, Colombia.

Cribb, P. J. \& R. Govaerts. 2005. Just how many orchids are there? Pp. 161-172 in: A. Raynal-Roques, A. Roguenant, \& D. Prat (eds.). Proceedings of the 18th World Orchid Conference. Naturalia Publications, Turriers, France.

Dressler, R. L. 2005. How many orchid species? Selbyana 26: $155-158$.

Food and Agriculture Organization of the United Nations. 1996. The state of the world's plant genetic resources for food and agriculture. FAO, Rome.

Knudson, L. 1946. A new nutrient solution for the germination of orchid seed. Amer. Orch. Soc. Bull. 14: 214-217.

Knudson, L. 1954. Storage and viability of orchid seed. Amer. Orch. Soc. Bull. 22: 260-261.

Linington, S. H. \& W. H. Pritchard. 2001. Gene banks. Pp. 165-181 in: S. A. Levin (ed.). Encyclopedia of biodiversity, Vol. 3. Academic Press, New York.

Murashige, T. \& F. Skoog. 1962. Tissue culture - a new means of clonal propagation of orchids. Amer. Orch. Soc. Bull. 33: 473-478.

Neto Machado, N. B. \& C. Castilho Custodio. 2005. Orchid conservation through seed banking: ins and outs. Selbyana 26: 229-235.

Niessen, A. \& E. Calderón. (ed.) 2002. Plan de Acción para la conservación de orquídeas del género Cattleya en Colombia - proyecto piloto. Instituto de Investigación de Recursos Biológicos Alexander von Humboldt. Boletín No. 30. 